\title{
MANUFACTURE AND PERFORMANCE EVALUATION OF A CIRCULAR SAW MOWER FOR CUTTING SOME CROP RESIDUES \\ Moheb M. A. El-Sharabasy*
}

ABSTRACT

The object of the present study was to manufacture and evaluate a small self propelled machine for cutting some crop residues grown during Egyptian summer season. It consists of twin saw circular discs and transmission system to transmit the rotating motion from the machine engine to the saw circular discs. This machine was constructed and evaluated to find out the optimum operating parameters for cutting cotton, maize and sunflower residues at four saw disc rotating speeds of 1500 (19.50), 1800 (23.40), 2100 (27.30) and 2500 (32.50), $\mathrm{rpm}(\mathrm{m} / \mathrm{s})$; four machine forward speeds of $0.8,1.0,1.2$ and $1.5 \mathrm{~km} / \mathrm{h}$ and four average stalks moisture contents of 18.45, 25.15, 31.20 and $42.10 \%$; 29.32, 37.66, 41.26 and $53.41 \%$ and 17.88, 23.27, 29.35 and $40.63 \%$ for cotton maize and sunflower stalks, respectively. The obtained results revealed that: Field capacity and cutting height increased as the kinematic parameter decreased. Field efficiency and cutting efficiency increased as the kinematic parameter increased. Required power and consumed energy decreased as the kinematic parameter decreased. Kinematic parameter of 81.98 recorded minimum criterion cost. Stalks moisture contents of 31.20, 41.26 and $29.35 \%$ considered the suitable values for cutting cotton, maize and sunflower residues, respectively.

\section{INTRODUCTION}

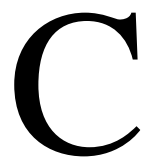

otton, maize and sunflower are the most important crops planted across all Egyptian summer fields. The cutting of stalks is an important process after harvesting period to clear the fields to be prepared for the next winter crops. The sickle, scythe, knife and hoe which were old traditional tools have been replaced by stalk cutting machines. These are the reciprocating types and the rotary impact types. The latter is being increasingly used in these operations due to its simplicity in construction, low maintenance cost and ability to cut both small and large diameter stalks (McRandal and McNulty, 1978). Awady et al. (1986) investigated the performance of rotary harvester in cutting cotton stalks by changing the forward speeds and the cutter cover. The rotary harvester was tested with a cutting saw have $25 \mathrm{~cm}$ diameter, from 600 to 1500 rpm and 60 teeth.

${ }^{*}$ Assist. Prof. of Agric. Eng., Fac. of Agric., Zagazig Univ., Egypt. 
The height of stubbles and the number of remaining uncut stalks were registered for the evaluation. They found that the low speed of $0.75 \mathrm{~km} / \mathrm{h}$ gave clean cut with high cutting efficiency of $93.3 \%$. A high speed of $1.35 \mathrm{~km} / \mathrm{h}$ gave a ruptured cut with low cutting efficiency of $83.3 \%$. Also, the forward speed of $1.15 \mathrm{~km} / \mathrm{h}$ gave the optimum rate of performance and field efficiency. Sahar (1988) mentioned that the use of big machinery for cutting crop residues is inappropriate for the following reasons: a) It needs high technical experience for operation and maintenance. b) High capital requirements. And c) Low field efficiency in small holdings and losses of straw are high on irregularly furrowed soils. Imbabi (1992) designed and developed a rotary harvester to be suitable for the reaping of sesame in the Egyptian farms circumstances. The designed and manufactured harvester was tested and evaluated with taking into consideration the followings: single and double cutter discs having 9,12 and 16 inch diameter, different forward speeds and different rotary speeds. The results could be summarized as: height of plant stubble after cutting ranged from 9.0 to $11.9 \mathrm{~cm}$, field capacity ranged from 0.10 to $0.20 \mathrm{fed} / \mathrm{h}$, field efficiency ranged from 70 to $90 \%$, the energy requirements ranged from 100 to $400 \mathrm{~kW} . \mathrm{h} /$ fed and the cost ranged from 15.81 to $59.58 \mathrm{LE} / \mathrm{fed}$. Morad (1995) stated that the proper adjustment of kinematic parameter for the rotary mower during the mowing operation is of great importance to increase crop yield and decrease cost requirements. Decreasing the rotary mower kinematic parameter lead to increase field capacity and cutting height, while decreased field efficiency, cutting efficiency, fuel consumption and energy requirements. Rotary mower kinematic parameter value of 25 minimized the mowing cost. Imbabi (1997) tested three shapes of cutter blades namely: cutter discs, circular saw and cutter blade in cutting maize stalks. He found that using circular saw is preferable at forward speed of $0.83 \mathrm{~km} / \mathrm{h}$ and rotary speed of $1200 \mathrm{rpm}$ (kinematic parameter of 83.22) which gave the highest cutting efficiency of $97.4 \%$, actual field capacity of about $0.1 \mathrm{fed} / \mathrm{h}$, useful time efficiency of $78.11 \%$, energy required of 104.10 $\mathrm{kW} . \mathrm{h} / \mathrm{fed}$ and lowest cutting cost of $11.50 \mathrm{~L} . \mathrm{E} / \mathrm{fed}$. Chattopadhyay and Pandey (2001) reported that the energy required for the cutting unit of stalk cutter may be categorized as: friction in the moving parts of the machine and air friction; kinetic energy required to accelerate the chopped material; energy required to overcome friction of the chopped material against the stationary parts of the machine; and energy required to cut the stalk. Lungkapin et al. (2007) indicated that the highest cutting quality of cassava cutting unit at more than 60 
number of circular saw teeth when operated at faster than $1200 \mathrm{rpm}$ cutting shaft speed and slower than $50 \mathrm{rpm}$ cam shaft speed. Cutting capacity depended on cam shaft speed. At $50 \mathrm{rpm}$ cam shaft speed, minimum cutting capacity was found to be 5034 stakes per hour (40272 stakes per day of 8 h) with $83.91 \%$ cutting efficiency. Hoseinzadeh et al. (2009) showed that the effects of wheat variety, knife bevel angle, moisture content and shearing speed on shearing energy were significant $(\mathrm{P}<0.01)$. Shearing energy decreased with decreasing moisture content and bevel angle and with increasing shearing speed. Maximum shearing energy was obtained with Kohdasht variety at $0.86 \mathrm{MJ} \mathrm{mm}^{-2}$. Tavakoli et al. (2009) found that an increase in moisture content of straw lead to a decrease in the bending strength and Young's modulus and an increase in the shear strength and specific shearing energy in weight straw. The aim of this work is to construct and evaluate a self-propelled machine for cutting cotton, maize and sunflower stalks in terms of cutting efficiency, field capacity and efficiency, energy and cost requirements as a function of change in saw disc speed, machine forward speed and stalks moisture contents.

\section{MATERIALS AND METHOD}

Field experiments were carried out at private farm in Damietta governorate during the summer season of 2010 to construct and evaluate the performance of a self-propelled cutting machine with twin rotating saw discs in the same direction.

\subsection{MATERIALS:}

\subsubsection{Crop residues:}

The crop residues used through the tests were cotton, maize and sunflower stalks having different characteristics, shown in Table 1.

Table 1. Characteristics of crop residues.

\begin{tabular}{lcccc}
\hline \multirow{2}{*}{ Crop characteristics } & \multicolumn{3}{c}{ Crop residues } & \multirow{2}{*}{ Unit } \\
\cline { 2 - 4 } & Cotton & Maize & Sunflower & \\
\hline Crop variety & Giza-86 & Giza-122 & Giza-102 & ---- \\
Av. Stalks length & 104.85 & 180.28 & 192.45 & $\mathrm{~mm}$ \\
Av. Stalks diameter & 11.5 & 25.1 & $2 \curlyvee . \wedge$ & $\mathrm{mm}$ \\
Av. Stalks population & 11.6 & 8.3 & 7.6 & Stalks $/ \mathrm{m}^{2}$ \\
\hline
\end{tabular}

\subsubsection{Cutting machine:}

A self propelled cutting machine was constructed and evaluated to overcome the problems appearing at using the traditional method for pulling or cutting cotton, maize and sunflower stalks manually with hand tools, which consumed more 
time, effort and cost. Also, the use of tractor with ordinary attached cutter bars or rotating discs machines could be compact the soil layers due to its heavy weight. To overcome these problems, a small self propelled machine was manufactured and evaluated to give the best cutting efficiency, adequate field capacity and efficiency, save energy consumed and total cost requirements, and also reduce soil compaction to the minimum values. The overall specifications and top view of the constructed cutting machine were given in Table 2, Fig.1. and Photo 1.

\section{Table 2. Overall specifications of the constructed saw cutting machine.}

\begin{tabular}{ll}
\hline Machine: & \\
\hline Model & Stiga Villa (Sweden made) \\
Gear box (Fast-Slow) & (5 forward \& 1 reverse) speeds \\
Power & $12.5 \mathrm{hp}(9.38 \mathrm{~kW})$ \\
Rated speed & $3200 \mathrm{rpm}$ \\
Fuel & Benzene \\
Working width & $120 \mathrm{~cm}$ \\
Overall length & $260 \mathrm{~cm}$ \\
Overall width & $100 \mathrm{~cm}$ \\
Overall height & $120 \mathrm{~cm}$ \\
\hline CCutting device: & \\
Saw disc (Same direction) & 2 \\
Swath bar & 2 \\
Gear box & 2 \\
Pulleys (one double and two single) & 3 \\
V-belt & 2 \\
\hline
\end{tabular}

The cutting device of the constructed machine consists of the followings:

a- Saw discs: The cutting machine have two serrated metal saw discs, each disc have diameter of $250 \mathrm{~mm}$, thickness of $1.2 \mathrm{~mm}$ and 40 teeth number. The two discs rotate in the same direction through a gear box and two pulleys having diameter of $100 \mathrm{~mm}$ and two other pulleys having diameter of $50 \mathrm{~mm}$ with connecting two $\mathrm{V}$ belts shown in Fig.1. and Photo 2.

b-Dividers: The developed cutting machine has two dividing units, each two dividers were fixed with the main frame. These dividers have a triangular shape and tapered front section to collect, catch and guide the stalks toward the saw circular disc. The machine includes two such units which has the following geometric dimensions, shown in Fig.1. and Photo 2.

- Length: is the horizontal length between the front and the rear ends, $640 \mathrm{~mm}$.

- Height: is the vertical length between the two divider edges, $100 \mathrm{~mm}$. The rear side of the divider connected to the main frame. 


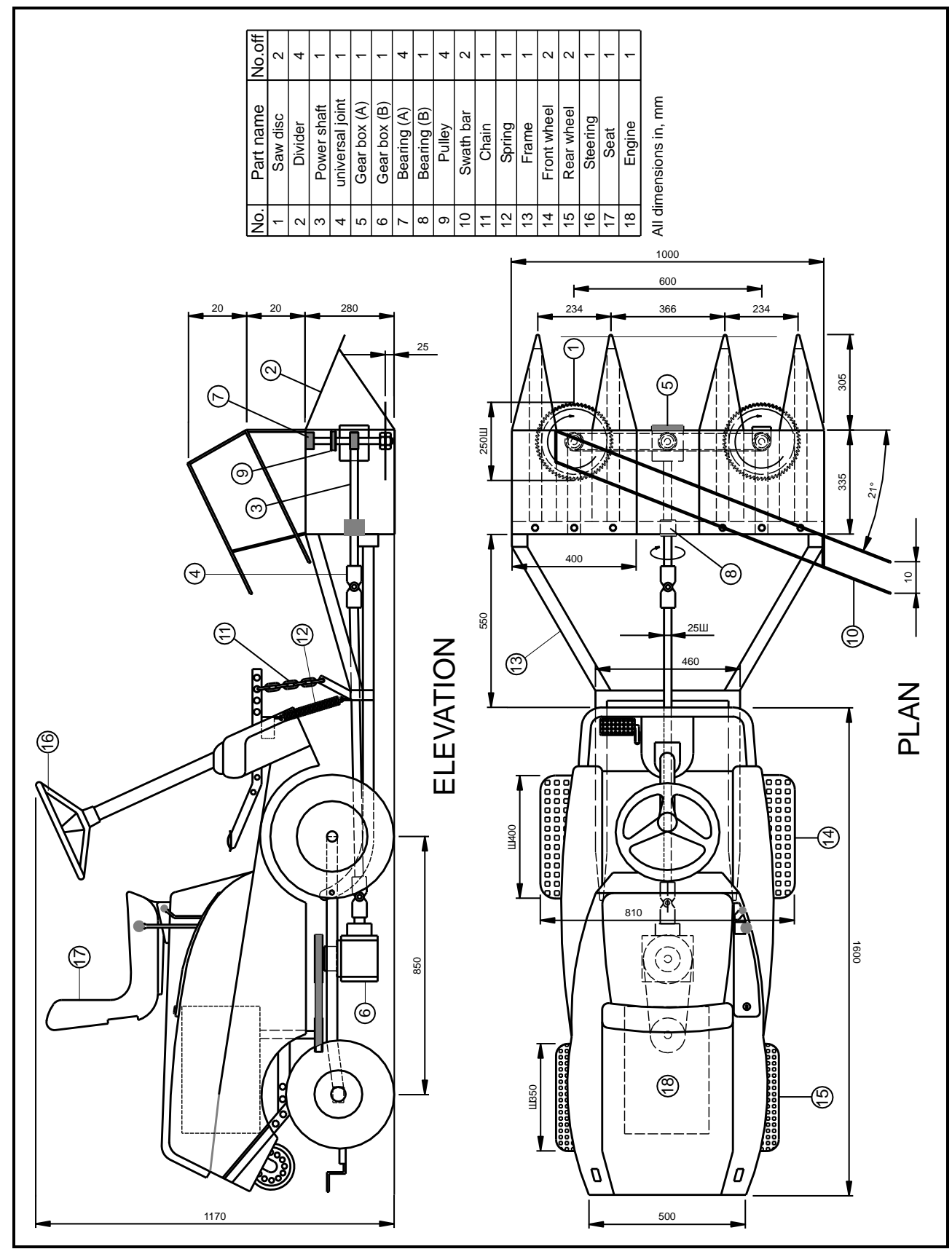

Fig.1. Elevation and plan of the developed saw disc-cutting machine.

- Forward peach: is the forward distance between the center line axis of two dividers in the same unit, $234 \mathrm{~mm}$, and $600 \mathrm{~mm}$ between the center line axes of the two units. 


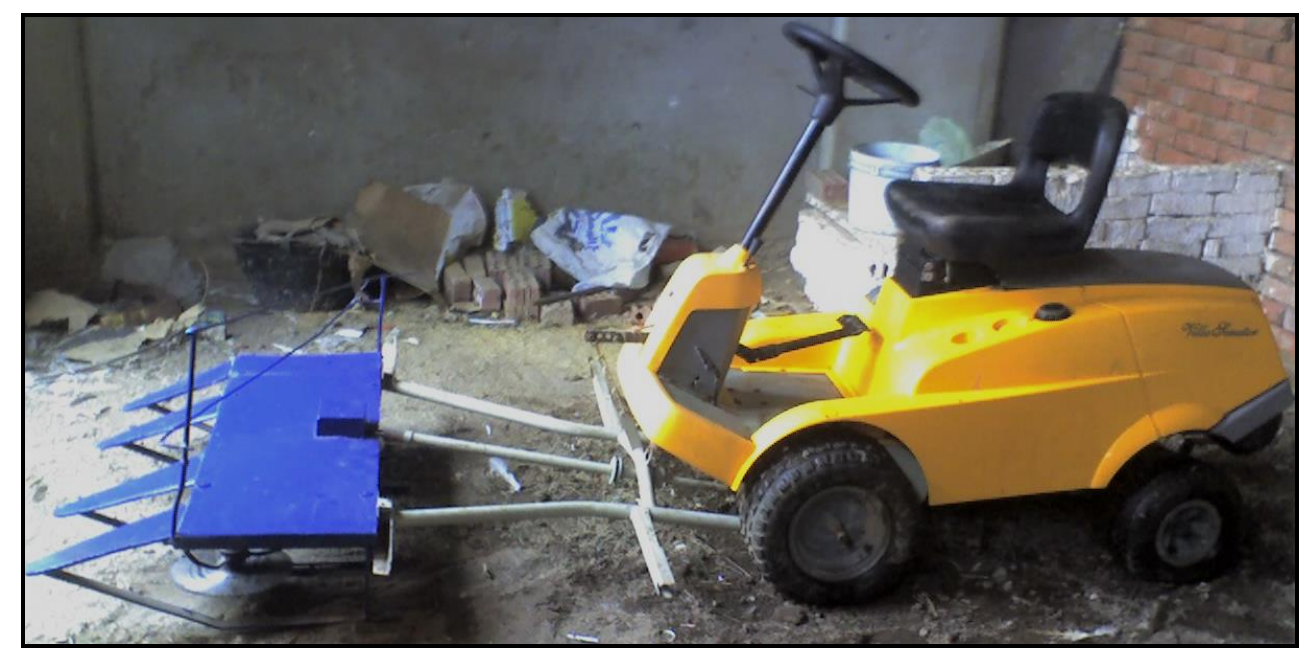

Photo 1. The constructed cutting machine.

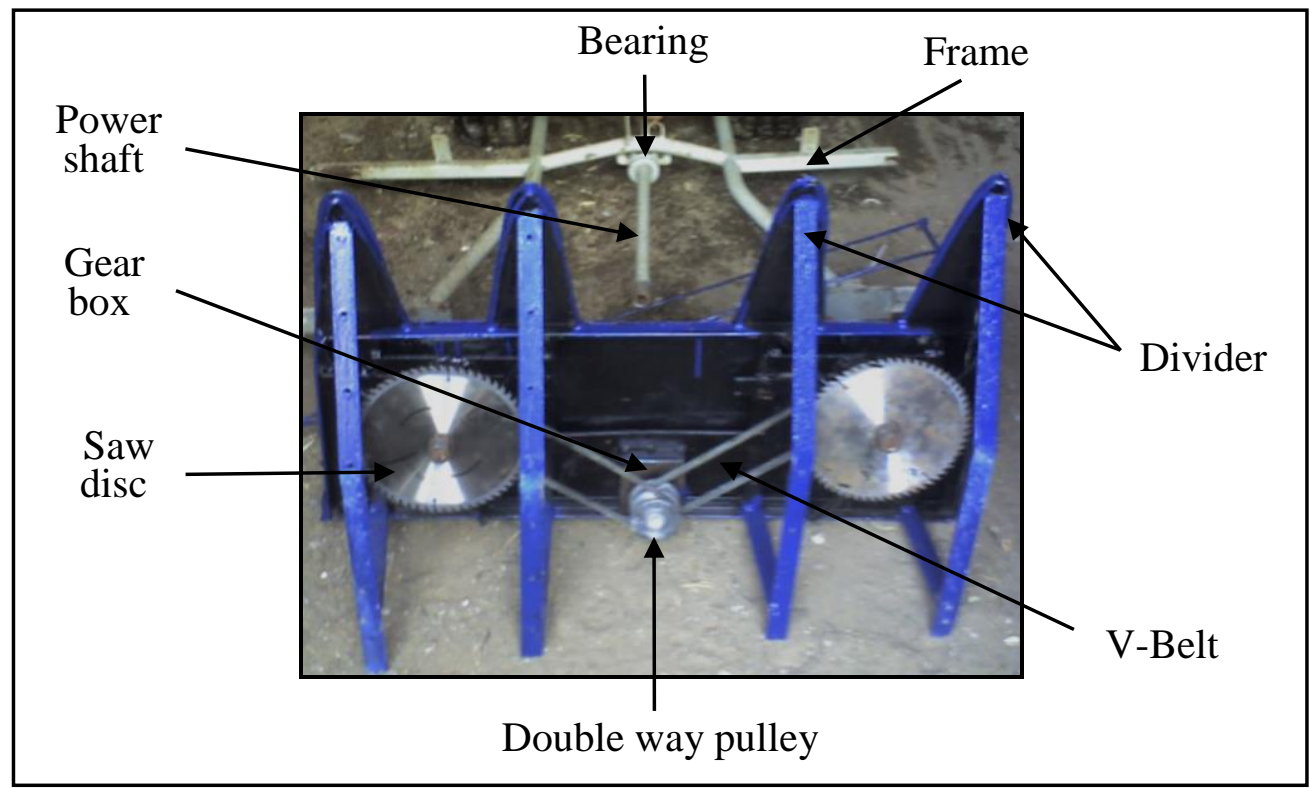

Photo 2. The constructed cutting device.

c-Swath bar: Two swath bars were fixed above the cutting unit to transport the cutting stalks at the right side of the machine. The swath bars made from steel, each one has dimensions of $5 \mathrm{~mm}$ in diameter and $1150 \mathrm{~mm}$ in length. The vertical distance between the two swath bars is $200 \mathrm{~mm}$, while the horizontal distance is $100 \mathrm{~mm}$ and the inclination angle of the rear end to the front is $21^{\circ}$ to keep the cutting stalks moving to the right side of the machine in a vertical position and also keep the stalks away from the operator. Fig.1 and Photo 1.

d-Transmission system: The power is transmitted from the machine engine to the saw rotating discs as shown in Fig. 2. 
- $3000 \mathrm{rpm}$ at engine pulley which has diameter of $112 \mathrm{~mm}$ can be transmitted to gear box (B) pulley having diameter of $150 \mathrm{~mm}$ using V-belt between the two pulleys to be equal $2100 \mathrm{rpm}$, with reduction ratio of $1: 1.43$.

- $2100 \mathrm{rpm}$ at gear box (B) pulley transported to the power shaft through a universal joint having length of $980 \mathrm{~mm}$.

- The power shaft transport its motion to the cutting saw discs through a small gear box (A) with constant ratio of 1: 1 .

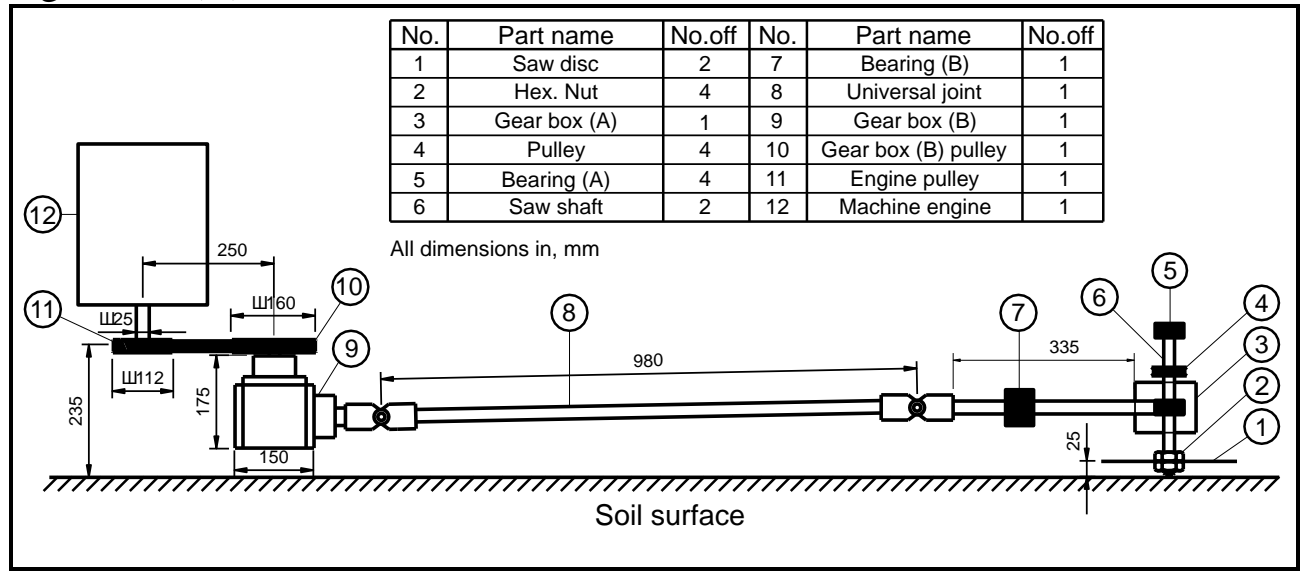

Fig. 2. Power transmission from machine engine to saw the discs.

\subsection{METHOD:}

The present study was conducted to investigate the optimum relation between speed of circular saw and machine forward speed (kinematic parameter) and their affect on maximum cutting efficiency, energy consumed and cutting cost for different crop stalks. The tungsten carbide tipped circular saw available in local market with (60 numbers of teeth and diameter of $250 \mathrm{~mm}$ ) was used in laboratory and field tests. The total experimental area was about 5.5 feddans divided into three sub blots of 1.75 feddans for cotton, maize and sunflower residues. The constructed cutting machine was operated at each crop after harvesting period and the stalks were ready to remove. The cutting machine was evaluated taking into consideration the following parameters:

- Types of crop residues: cotton, maize and sunflower stalks.

- Saw disc rotating speeds: 1500 (19.50), 1800 (23.40), 2100 (27.30) and 2500 (32.50) (m/s) rpm.

- Machine forward speeds: 0.8, 1.0, 1.2 and $1.5 \mathrm{~km} / \mathrm{h}$.

- Stalks moisture contents: cotton $(18.45,25.15,31.20$, and $42.10 \%$ ), maize $(29.32,37.66,41.26$ and $53.41 \%)$ and sunflower $(17.88,23.27,29.35$ and $40.63 \%$ ) in average. 
The moisture contents of stalks were measured according to ASAE Standard S.352 (ASAE, 1979) in laboratory of faculty of agriculture, Zagazig University. The sample of stalks (from one third at the bottom part) was kept in an oven for 24 hours at $105{ }^{\circ} \mathrm{C}$. The loss in weight of the sample was recorded and the moisture content in percent was determined as in equation (1).

$$
\text { M. } \mathrm{C}_{\mathrm{wb}}=\left(\mathrm{W}_{\mathrm{i}} \times \mathrm{W}_{\mathrm{d}} / \mathrm{W}_{\mathrm{i}}\right) \times 100
$$

Where: $\mathrm{M} \cdot \mathrm{C}_{\mathrm{wb}}=$ moisture content, $(\%)$.

$\mathrm{W}_{\mathrm{i}}=$ Initial weight of sample, $(\mathrm{kg}) . \quad \mathrm{W}_{\mathrm{d}}=$ dried weight of sample, $(\mathrm{kg})$.

\subsection{MEASUREMENTS:}

2.3.1. Cutting efficiency: was calculated using the following formula:

$$
\mathrm{E}_{\mathrm{C}}=\frac{\mathrm{A}-\mathrm{B}}{\mathrm{A}} \times 100
$$

Where: $\mathrm{E}_{\mathrm{C}}=$ Cutting efficiency, $(\%)$.

$\mathrm{A}=$ Height of plant stalks above the soil before cutting, $\mathrm{cm}$.

$\mathrm{B}=$ Height of plant stalks above the soil after cutting, $\mathrm{cm}$.

2.3.2. Actual field capacity: was the actual average time consumed during digging operation (lost time + productive time). It can be determined from the following equation:

$$
\text { F.C } \mathrm{C}_{\mathrm{act}}=\frac{60}{\mathrm{Tu}+\mathrm{Ti}}, \quad \mathrm{fed} / \mathrm{h}
$$

Where: $\mathrm{F} \cdot \mathrm{C}_{\mathrm{act}}=$ Actual field capacity of the cutting machine.

$\mathrm{T}_{\mathrm{u}}=$ Utilization time per feddan in minutes.

$\mathrm{T}_{\mathrm{i}}=$ Summation of lost time per feddan in minutes.

- Field efficiency: was calculated by using the values of the theoretical field capacity and effective field capacity rates as:

$$
\eta_{\mathrm{f}}=\frac{\mathrm{F} \cdot \mathrm{C}_{\mathrm{act}}}{\mathrm{F} \cdot \mathrm{C}_{\mathrm{th}}} \times 100, \quad \%
$$

Where: $\eta_{\mathrm{f}}=$ Field efficiency, \%.

2.3.3. Energy consumed: To estimate the engine power during cutting process, the decrease in gasoline fuel level in fuel tank accurately measuring immediately after each treatment. The following formula was used to estimate the engine power (Hunt, 1983):

$$
\mathrm{EP}=\left[\mathrm{F} . \mathrm{C}(1 / 3600) \rho \mathrm{f} \times \mathrm{L} . \mathrm{C} . \mathrm{V} \times 427 \times \eta_{\mathrm{thb}} \times \eta_{\mathrm{m}} \times(1 / 75) \times(1 / 1.36)\right], \mathrm{kW}(5)
$$

Where: F.C $=$ Fuel consumption, $(1 / h)$.

$\rho f=$ Density of fuel, $(\mathrm{kg} / \mathrm{l})$, (for gasoline $=0.72)$.

L.C.V = Calorific value of fuel, $(11.000 \mathrm{k} . \mathrm{cal} / \mathrm{kg})$. 
$\eta_{\text {thb }}=$ Thermal efficiency of the engine, (for Otto engine, $25 \%$,).

$427=$ Thermo-mechanical equivalent, (kg.m/k.cal).

$\eta_{\mathrm{m}}=$ Mechanical efficiency of the engine, (for Otto engine, $85 \%$ ).

The energy can be calculated as following:

$$
\text { Energy consumed }=\frac{\text { Engine power, }(\mathrm{kW})}{\text { Actual field capacity, }(\mathrm{fed} / \mathrm{h})}, \quad \mathrm{kW} . \mathrm{h} / \mathrm{fed}
$$

2.3.4. Cutting cost: The operating cost of spreading operation was estimated using the following equation (Awady et al. 1982):

$$
\text { Operating cost }=\frac{\text { Machine } \operatorname{cost}(\mathrm{L} . \mathrm{E} / \mathrm{h})}{\text { Actual field } \operatorname{capacity}(\mathrm{fed} / \mathrm{h})}, \quad \text { L.E/fed }
$$

Machine cost was determined by using the following equation (Awady, 1978):

$$
\mathrm{C}=\frac{\mathrm{P}}{\mathrm{h}}\left(\frac{1}{\mathrm{a}}+\frac{\mathrm{i}}{2}+\mathrm{t}+\mathrm{r}\right)+(1.2 \text { W.S.F })+\frac{\mathrm{m}}{144}
$$

Where:

$\mathrm{C}=$ Hourly cost, L.E/h.

$\mathrm{h}=$ Yearly working hours, $\mathrm{h} /$ year.

$\mathrm{i}=$ Interest rate/year.

$\mathrm{t}=$ Taxes, over heads ratio.

$\mathrm{r}=$ Repairs and maintenance ratio.

$\mathrm{m}=$ Monthly average wage, $\mathrm{L} . \mathrm{E}$
$\mathrm{P}=$ Price of machine, L.E.

A $=$ Life expectancy of the machine, $y$.

$1.2=$ Factor accounting for lubrications

$\mathrm{W}=$ Engine power, $\mathrm{hp}$.

$\mathrm{F}=$ Fuel price, $\mathrm{L}$.E/l.

$\mathrm{S}=$ Specific fuel consumption, $1 / \mathrm{hp} . \mathrm{h}$.

$144=$ Reasonable estimation of monthly working hours.

The criterion cost was determined using the following equation (Awady et al. 1982):

Criterion cost $=($ operating cost + product losses cost $), \quad$ L.E/fed

Product losses cost $=($ stalk yield/fed $)\left(100-\eta_{\text {cut }}\right)($ stalk price $/ \mathrm{kg})$, L.E/fed $\quad(10)$

\section{RESULTS AND DISCUSSION}

From the pre experimental tests, it could be noticed that the circular saw could be rotated at maximum speed of $3000 \mathrm{rpm}$ at different machine forward speeds, which represents different kinematic parameters as shown in Table 3. It was observed that the kinematic parameter around 80 is the suitable one, which gave a clean cutting shape and adequate cutting efficiencies in different crop stalks. So that, the constructed cutting machine was operated under constant saw rotating speed of $2100 \mathrm{rpm}(27.30 \mathrm{~m} / \mathrm{s})$ and different forward speeds to investigate the effect of saw rotating speed, machine forward speed (kinematic parameter) and type of crop residues and their moisture contents on machine performance. 
Table 3. Kinematic parameters at different saw rotating speeds and different machine forward speeds.

\begin{tabular}{cccccc}
\hline \multirow{2}{*}{ Machine forward speed } & \multicolumn{4}{c}{ Saw disc rotating speed, $(\mathbf{r p m})$} \\
\cline { 3 - 5 } & & $\mathbf{1 5 0 0}$ & $\mathbf{1 8 0 0}$ & $\mathbf{2 1 0 0}$ & $\mathbf{2 5 0 0}$ \\
\cline { 2 - 5 } & $\mathbf{( m / s )}$ & $\mathbf{1 9 . 5 0}$ & $\mathbf{2 3 . 4 0}$ & $\mathbf{2 7 . 3 0}$ & $\mathbf{3 2 . 5 0}$ \\
\hline $\mathbf{( k m} / \mathbf{h})$ & $\mathbf{0 . 2 2 2}$ & 87.84 & 105.41 & 122.97 & 146.40 \\
$\mathbf{0 . 8}$ & $\mathbf{0 . 2 7 8}$ & 70.14 & 84.17 & 98.20 & 116.91 \\
$\mathbf{1 . 0}$ & $\mathbf{0 . 3 3 3}$ & 58.56 & 70.27 & 81.98 & 97.60 \\
$\mathbf{1 . 2}$ & $\mathbf{0 . 4 1 7}$ & 46.76 & 56.12 & 65.47 & 77.94 \\
$\mathbf{1 . 5}$ & &
\end{tabular}

3.1. Cutting height and cutting efficiency:

3.1.1. Effect of kinematic parameter on cutting height and cutting efficiency:

Fig.3. presents the relationship betwœen kinematic parameter and both cutting height and cutting efficiency at different crop stalks and different moisture contents. Results show that the cutting efficiencies decreased with decrease in kinematic parameter and their maximum values of $97.15,96.55$ and $98.05 \%$ corresponding to high kinematic parameter of 122.27 with cutting heights of $2.99,6.22$ and $3.75 \mathrm{~cm}$ at different staks moisture contents of $31.20,41.26$ and $29.35 \%$ for cotton, maize and sunflower, respectively. While the minimum values of the cutting efficiencies were $80.00,85.10$ and $81.42 \%$ with cutting heights of 20.97, 26.86 and $35.76 \mathrm{~cm}$ at low kinematic parameter of 63.93 at different staks moi sture contents of 42.10, 53.41 and $40.63 \%$ for cotton, maize and sunflower, respectively. The decrease in cutting efficiency at low kinematic parameter can be explained by the fact that at higher forward speed the impact force was small to sufficiently cut the stalks.

\subsubsection{Effect of stalks moisture content on cutting height and efficiency:}

Fig.3. shows the effect of stalks moisture content on cutting efficiency. The optimum values of moisture contents, which gave maximum cutting efficiencies of $97.15,96.55$ and $98.05 \%$ (cutting heights of 2.99, 6.22 and $3.75 \mathrm{~cm}$ ) were $31.20,41.26$ and $29.35 \%$ for cotton, maize and sunflower, respectively. Any further decrease less to or increase more than these values, the cutting efficiency decreased to $90.65,92.65$ and $91.80 \% ; 88.25,91.00$ and $89.85 \%$ since the cutting height increased to $9.80,13.25$ and $15.78 \mathrm{~cm} ; 12.32,16.23$ and $19.53 \mathrm{~cm}$ for cotton, maize and sunflower, respectively. Decreasing stalks moisture content under the optimum values lead to decrease cutting efficiency due to uneven conditions to operate the machine since the stalks are too dry. 


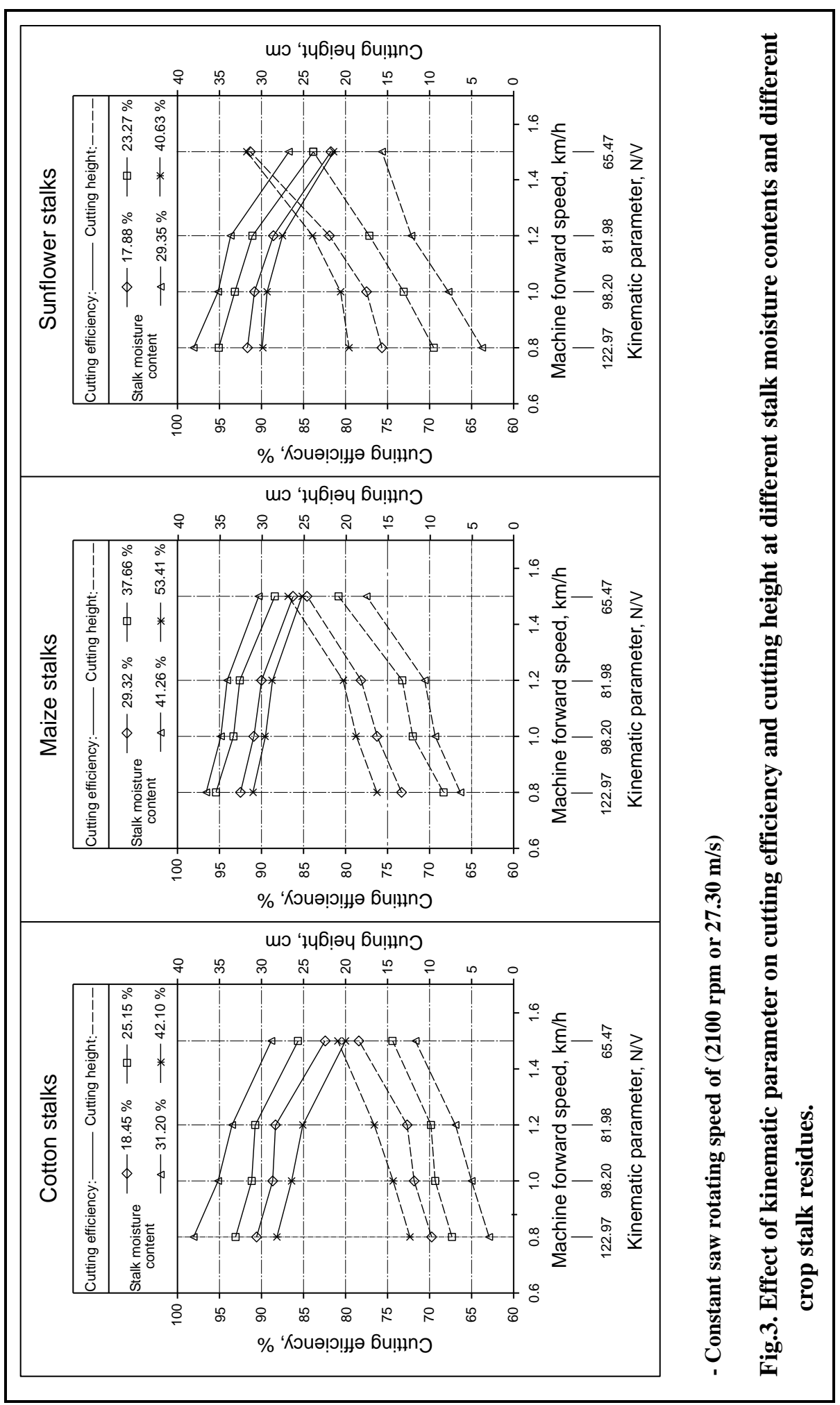


Also, increasing stalks moisture content above opti mum values leads to decrease cutting efficiency due to more elastic conditions for stalks resulting in more bending and un-cutting stalks.

\subsubsection{Effect of crop type on cutting efficiency:}

Relating to the effect of crop type on cutting efficiency, Fig.3. illustrated that the sunflower stalks recorded the maximum cutting efficiency of $98.05 \%$, followed by cotton stalks of $97.15 \%$ followed by maize stalks of $96.55 \%$ under constant kinematic parameter of 122.97 and stalks moisture contents of 29.35, 31.20, 41.26 and $\%$ for sunflower, cotton and maize, respectively. The deference values between these cutting efficiencies were too smal since the saw cutting disc clear the area smoothly and the differences may be attributed to the construction of sunflower staks, which were very easy to cut, compared with cotton stalks followed by maize stalks.

\subsection{Field capacity and field efficiency:}

3.2.1. Effect of kinematic parameter on field capacity and field efficiency:

Fig.4. show that the field capacity and field efficiency are highly affected by the change in kinematic parameter values. Decreasing the saw mower kinematic parameter from 122.97 to 65.47 increased the field capacity from 0.206 to 0.304 , from 0.217 to 0.326 and from 0.224 to $0.336 \mathrm{fed} / \mathrm{h}$, while the field efficiency decreased from 89.66 to 70.62 , from 94.44 to 75.90 and from 97.22 to $78.22 \%$ at lower stalk moisture contents of $31.20,41.26$ and $29.35 \%$ for cotton, maize and sunflower, respectively. The increase in field capacities and reduction in field efficiencies by decreasing the kinematic parameter are due to the less theoretical time consumed in comparison with the other items of time loss.

\subsubsection{Effect of stalks moisture content on field capacity and field efficiency:}

Fig.4. shows that generally, increasing stalks moisture content led to decrease both field capacity and field efficiency at different machine forward speeds. Increasing stalks moisture contents from 18.45 to $42.10 \%$; from 29.32 to 53.41 $\%$ and from 17.88 to $40.63 \%$, led to decrease the field capacities and field efficiencies from 0.277 to 0.247 , from 0.283 to 0.249 and from 0.298 to 0.266 fed/h; from 81.61 to 72.60 , from 83.33 to 73.20 and from 87.65 to $78.22 \%$ at constant machine forward speed of $1.2 \mathrm{~km} / \mathrm{h}$, for cotton, maize and sunflower, respectively. The decrease in both field capacities and field efficiencies by increasing stalks moisture content may be attributed to more elastic conditions for the stalks resulting in more resistance for cutting action. 


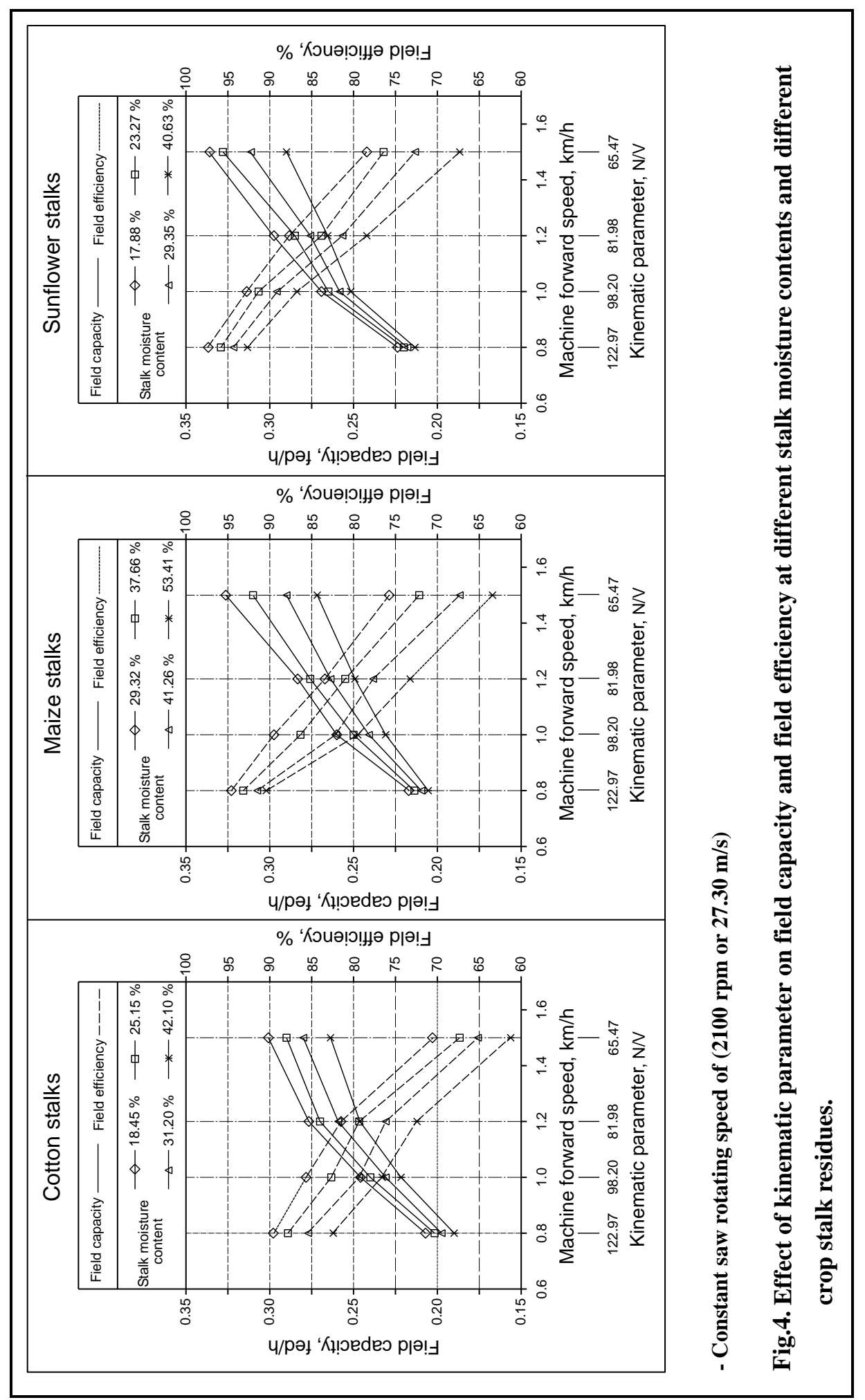




\subsubsection{Effect of crop type on field capacity and efficiency:}

The field capacity and field efficiency are greatly affected by the crop type. Fig.4. shows that at the same kinematic parameter of 81.98 and the optimum stalks moisture contents of $31.20,41.26$ and $29.35 \%$, the field capacity and field efficiency were found to be $0.259 \mathrm{fed} / \mathrm{h}$ and $72.60 \%$ for cotton crop less than $0.264 \mathrm{fed} / \mathrm{h}$ and $77.62 \%$ for maize crop less than $0.276 \mathrm{fed} / \mathrm{h}$ and $81.25 \%$ for sunflower crop. These results illustrated that the good standing and no branching for sunflower and maize crops increased both field capacity and field efficiency since the cutting efficiency was also very good.

\subsection{Required power and consumed energy:}

\subsubsection{Effect of kinematic parameter on power and consumed energy:}

Required power as well as consumed energy is too related to kinematic parameter. Fig.5. shows that both required power and consumed energy decreased as the kinematic parameter decreased. Decreasing saw mower kinematic parameter from 122.97 to 65.47 decreased the required power from 8.29 to 4.96 , from 7.11 to 4.43 and from 6.44 to $3.85 \mathrm{~kW}$; from 40.26 to 16.30 , from 32.76 to 13.59 and from 28.75 to $11.46 \mathrm{~kW}$.h/fed, at lower stalks moisture content of $18.45,29.32$ and $17.88 \%$ for cotton, maize and sunflower, respectively. The decrease of required power and consumed energy by decreasing the kinematic parameter may be attributed to the increase of field capacity, resulted in low values of fuel and consumed energy in the unit area

\subsubsection{Effect of stalks moisture content on power and consumed energy:}

Fig.5. shows that the stalks moisture contents of 31.20, 41.26 and $29.35 \%$ are considered the optimum values during cutting cotton, maize and sunflower, respectively which recorded the minimum required power and consumed energy of $3.31 \mathrm{~kW}, 11.82 \mathrm{~kW} . \mathrm{h} / \mathrm{fed} ; 3.29 \mathrm{~kW}, 11.34 \mathrm{~kW} . \mathrm{h} / \mathrm{fed}$ and $3.19 \mathrm{~kW}, 10.22$ $\mathrm{kW} . \mathrm{h} / \mathrm{fed}$, respectively at lower kinematic parameter of 65.47. Any further decrease or increase in stalks moisture content less to or more than the optimum values mentioned above, both required power and consumed energy increased under all experimental conditions due to the increase in cutting resistance force lower moisture contents and increase elastic plant conditions at higher moisture contents which consumed more fuel during cutting operation.

\subsubsection{Effect of crop type on required power and consumed energy:}

Required power and consumed energy varied with the crop type. Results in Fig.5. shows that cotton stalks required more power and consumed energy than maize than sunflower. 


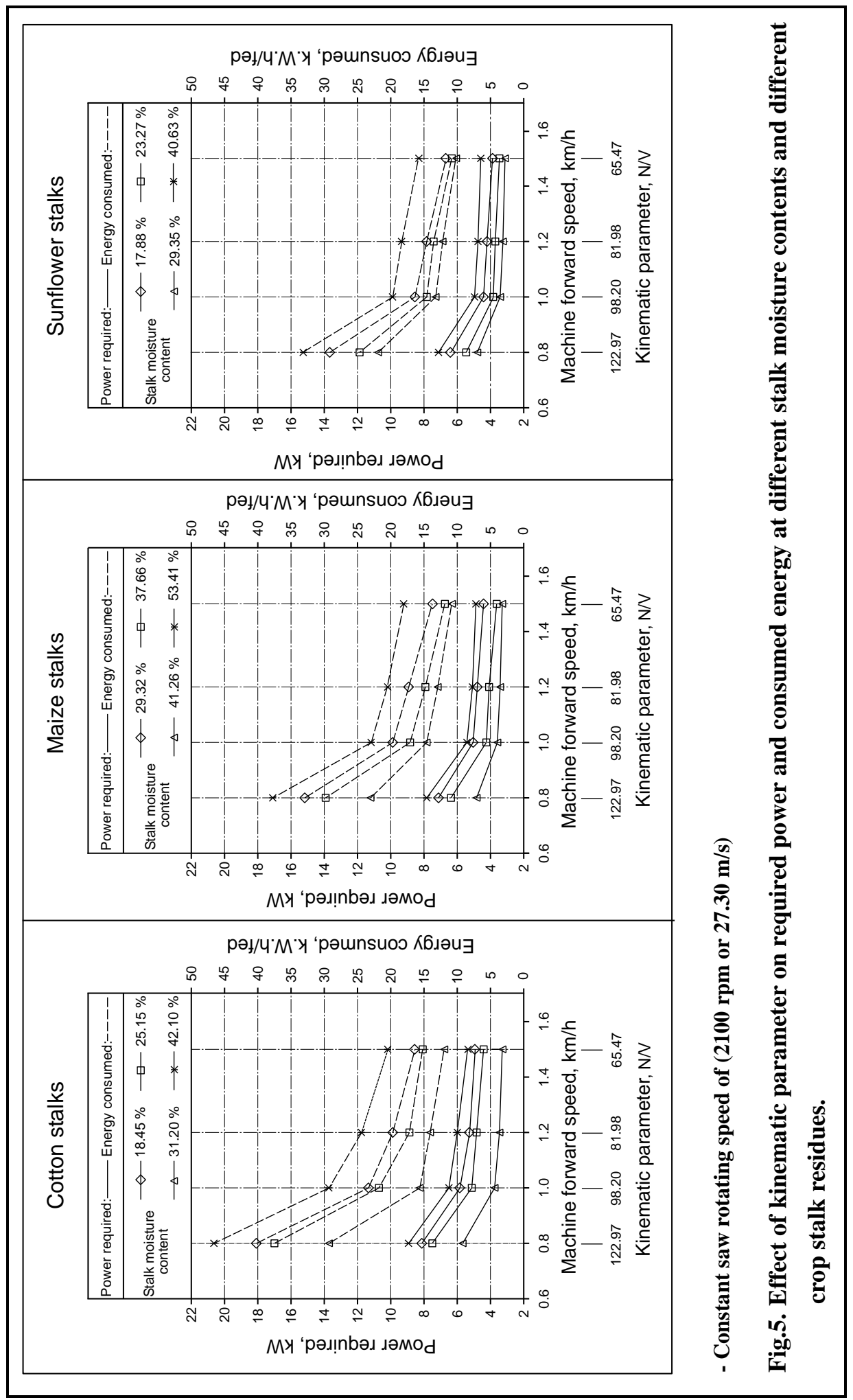


This is due to the high resistance of cotton stems-solid- comparing with maize and sunflower stems which were hollow stems. The cotton stalks recorded higher required power and consumed energy of $8.90 \mathrm{~kW}, 46.84 \mathrm{~kW} . \mathrm{h} / \mathrm{fed}$ followed by maize stalks of $7.76 \mathrm{~kW}, 37.67 \mathrm{~kW} . \mathrm{h} /$ fed followed by sunflower stalks of $7.10 \mathrm{~kW}, 33.33 \mathrm{~kW} . \mathrm{h} / \mathrm{fed}$ at constant kinematic parameter of 65.47 and different stalks moisture contents of 42.10, 53.41 and $40.63 \%$, respectively.

\subsection{Cutting cost requirements:}

\subsubsection{Effect of kinematic parameter on cutting cost requirements:}

Fig.6. shows that, decreasing kinematic parameter of saw mower from 122.97 to 65.47, decreased operating costs from 111.42 to 78.39 , from 104.52 to 75.69 and from 101.15 to 70.35 .L.E/fed at different stalks moisture contents of 31.20, 41.26 and $29.35 \%$ for cotton, maize and sunflower, respectively, while decreasing kinematic parameter of saw mower from 122.97 to 81.98 , decreased criterion costs from 116.61 to 96.76 , from 124.81 to 117.83 and from 104.17 to 89.26 L.E/fed at different stalks moisture contents of 31.20, 41.26 and $29.35 \%$ for cotton, maize and sunflower, respectively. Any further decrease in kinematic parameter from 81.98 to 65.47 , the criterion costs increased from 96.76 to 98.52 , from 117.83 to 132.61 and from 89.26 to 90.73 L.E/fed for cotton, maize and sunflower, respectively. The higher values of criterion costs at lower saw mower kinematic parameter were attributed to the increase of cutting height, resulting in considerable increase of stalks losses.

\subsubsection{Effect of stalks moisture content on cutting cost requirements:}

Fig.6. shows the effect of stalks moisture content on operating and criterion costs. The optimum stalks moisture contents which recorded the minimum criterion costs of 96.76, 117.83 and 89.26 L.E/fed, were 31.20, 41.26 and 29.35 $\%$ for cotton, maize and sunflower, respectively. Any further decrease in stalks moisture contents less to the optimum values led to increase the criterion costs from 96.76 to 101.01 , from 117.83 to 136.36 and from 89.26 to $91.33 \mathrm{~L} . E / f e d$ during cutting cotton, maize and sunflower, respectively. While any further increase in stalks moisture contents more than the optimum values led to increase the criterion costs al so from 96.76 to 116.08 , from 117.83 to 154.01 and from 89.26 to $101.82 \mathrm{~L}$.E/fed during cutting cotton, maize and sunflower, respectively. The higher values of criterion costs at lower or higher stalks moisture contents were attributed to the lower values of cutting efficiencies resulting in more stalks stubbles after cutting operation. 


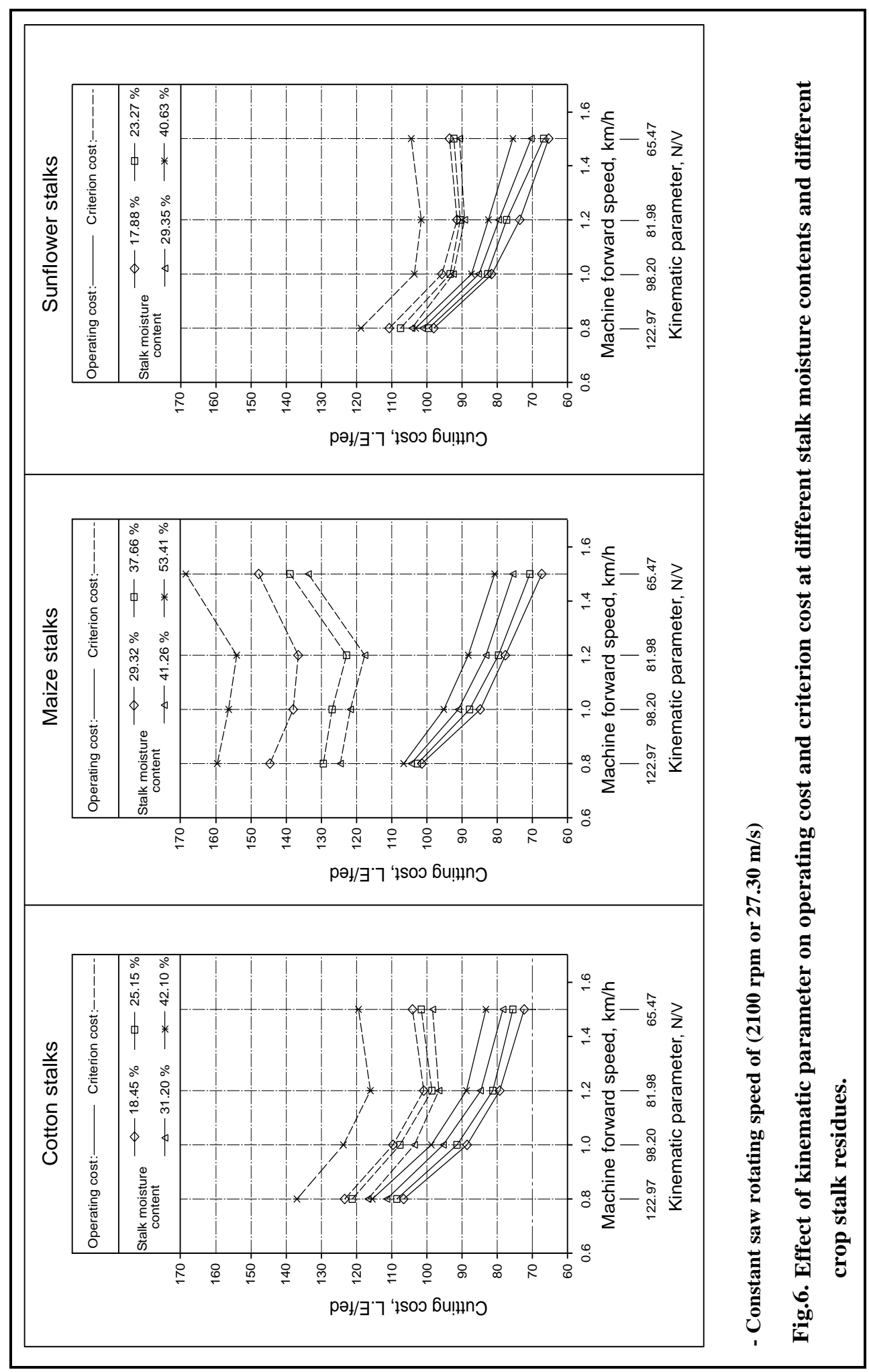




\subsubsection{Effect of crop type on cutting cost requirements:}

Fig.6. shows that the crop type was clearly affected on operating and criterion costs. Sunflower crop recorded the minimum criterion cost of 89.26 L.E/fed followed by cotton crop which recorded 96.76 L.E/fed followed by maize crop which recorded $117.83 \mathrm{~L} . \mathrm{E} / \mathrm{fed}$ at constant kinematic parameter of 81.98 and optimum stalks moisture contents of $29.35,31.20$ and $41.26 \%$ for sunflower, cotton and maize, respectively.

\section{CONCLUSION}

A manufactured self propelled machine with two saw discs constructed at the front of the mower was evaluated during cutting operation of cotton, maize and sunflower residues versus different kinematic parameters and different stalks moisture contents. From the obtained data, it can be concluded the followings: The proper adjustments of saw mower kinematic parameter and stalk moisture contents during cutting operation are great importance to increase cutting efficiency and decrease cost requirements. The most economical kinematic parameter is 81.98 , which represents the least criterion cost per feddan during cutting cotton, maize and sunflower stalks. Decreasing the saw mower kinematic parameter increased both field capacity and cutting height, while decreased field efficiency, cutting efficiency, required power and consumed energy. The optimum stalks moisture contents, which recorded minimum criterion costs were $31.20,41.26$ and $29.35 \%$ for cotton, maize and sunflower, respectively.

\section{REFERENCES}

ASAE (1994): Standards engineering practices data. Library of congress by the American society of Agric. Eng. Pp: 450.

Awady, M. N. (1978): Tractor and farm machinery. Text book, Faculty of Agriculture, Ain-Shams University. Pp: 164-167.

Awady, M. N; E. Y. Ghoneim and A. A. El-Nakib (1985): Cotton stalk pulling force and energy requirement. Misr J. Agric. Eng., 2(2): 3-15.

Awady, M. N; E. Y. Ghoneim and A. I. Hashish (1982): A critical comparison between wheat combine harvester under Egyptian conditions. R. S. No. 1920, Ain-Shams University. (FAO) Journal.

Awady, M. N; E. Y. Ghoniem and E. A. Sahar (1986): Evaluation of a rotary harvesters in cutting cotton stalk. Misr J. Agric. Eng., 3(2): 59-68.

Chattopadhyay, P. S and K. P. Pandey (2001): Impact cutting behaviour of sorghum stalks using a flail-cutter-a mathematical model and its verification. Journal of agricultural Engineering Research, 78(4): 369-376. 
Hoseinzadeh, B; A. Esehaghbeygi and N. Raghami (2009): Effect of moisture content, bevel angle and cutting speed on shearing energy of three wheat varieties. World Applied Sciences Journal, 7 (9): 1120-1123.

Hunt, D. (1983): Farm power and machinery management. $8^{\text {th }}$ Ed. Iowa state Univ., Press Ames, USA. Ames, Iowa, USA: 364-368.

Imbabi, A. T. (1992): Design and development of rotary harvester for sesame crop. Ph. D. Thesis, Agric. Eng. Dept., Fac. Of Agric., Cairo Uni., Egypt.

Imbabi, A. T. (1997): Performance of three different shapes of rotary cutter during cutting maize stalks. Misr J. Agric. Eng., 14(2): 229-246.

Lungkapin, J; V. M. Salokhe, R. Kalsirisilp and H. Nakashima (2007): Laboratory studies of the stem cutting unit of a cassava planter. Agricultural Engineering International: the CIGR E journal. July, 2007.

Mc Randal, D. M. and P. B. Mc Nulty (1978): Impact cutting behavior of forage crops. Mathematical models and laboratory test. Journal of Agricultural Engineering Research, 23 (3): 313-328.

Morad, M. M. (1995): optimizing the rotary mower kinematic parameter for minimum mowing cost. Misr J. Agric. Eng., 12 (2): 353-363.

Sahar, E. A. (1988): Design of a harvester appropriate for Egyptian agriculture. M. Sc. Thesis, Agric. Eng. Dept., Fac. of Agric., Ain Shams Uni., Egypt.

Tavakoli H; SS. Mohtasebi and A. Jafari (2009): Physical and mechanical properties of wheat straw as influenced by moisture content. Agro physics, 23:175-181.

الملخص العربي

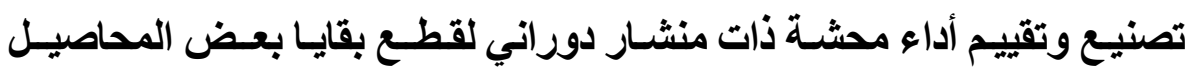

\section{د. محب محمد أنيس الثرباصي*}

يهذف هذا البحث إلى تصنيع وتقييم أداء آلة لقطع سيقان المحاصيل الأكثر شيو عاً في الموسم الصيفي في

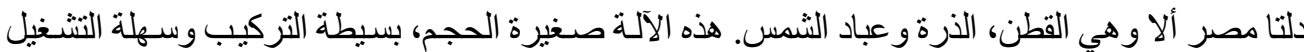

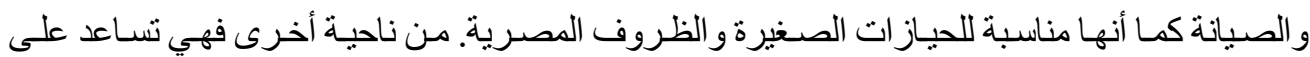

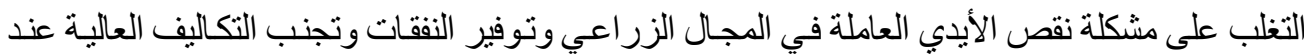

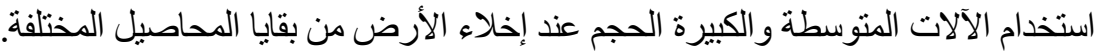

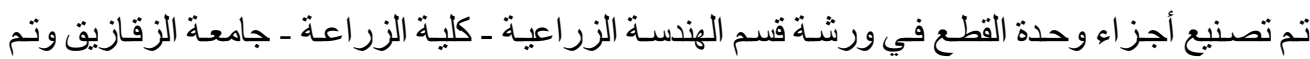
اختبار ها في أحد المز ارع الخاصة بمحافظة دمياط. تتركب هذه الألة الآلة من الأجز اء الآتية:

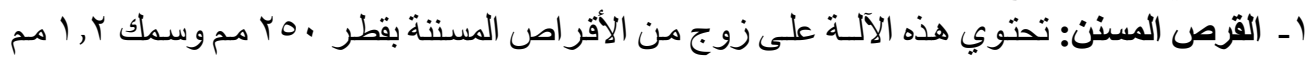

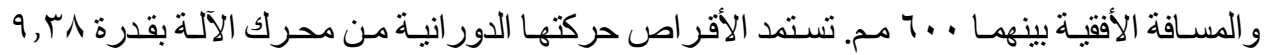

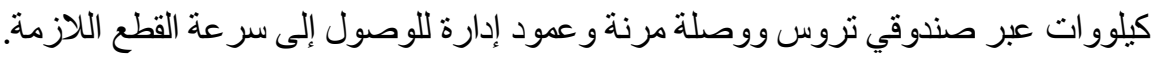
*أستاذ مساعد ـ قسم الهندة الزراعية ـ كلية الزراعة - جامعة الزقازيق - مصر. 


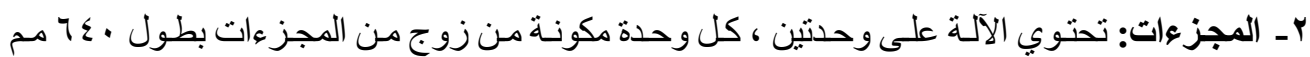

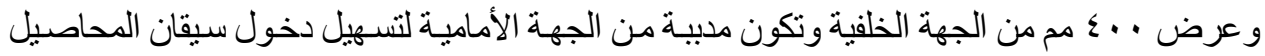

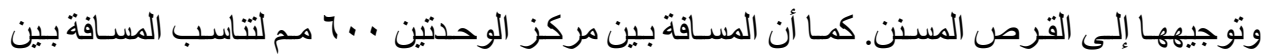
صفوف بقايا النباتات المطلوب قطعها.

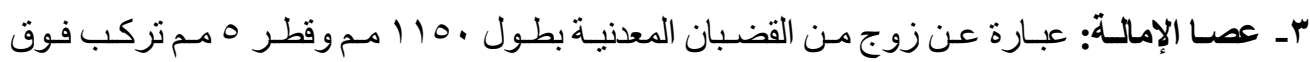

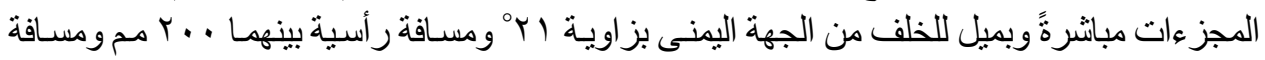

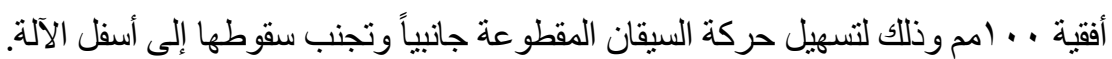

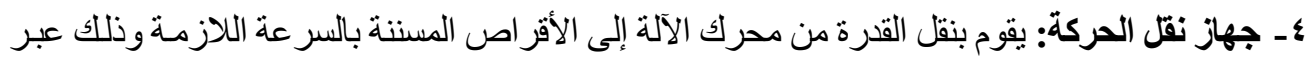

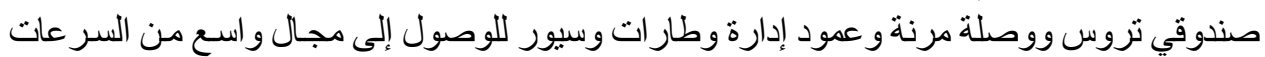

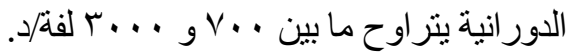

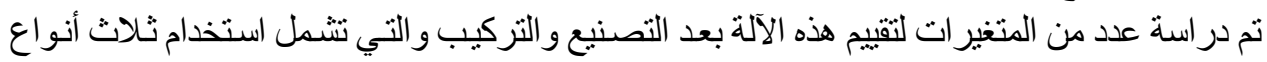

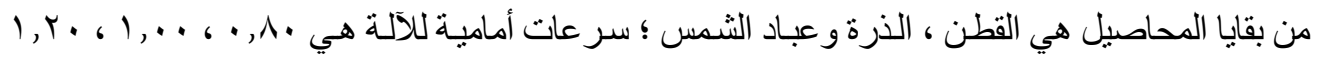

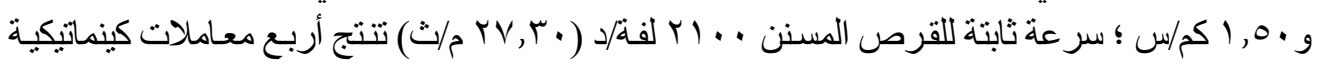

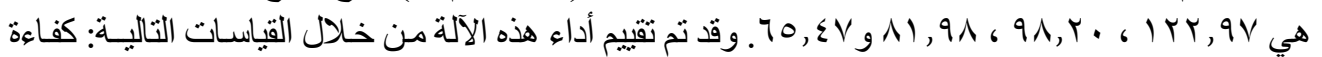

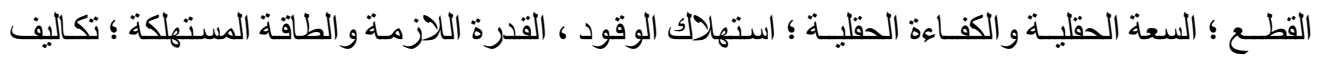
التشغيل والتكاليف الكليـة لعمليـة التقطيع.

\section{وقد أظهرت النتائج المتحصل عليها ما يلي:}

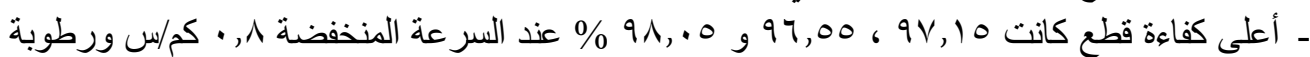

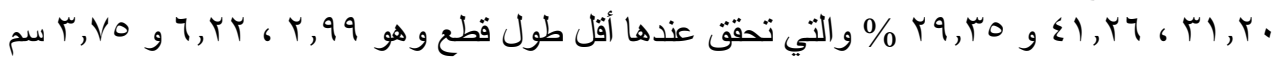
لكل من القطن ، الذرة و عباد الثمس ، و ، على الترتيب.

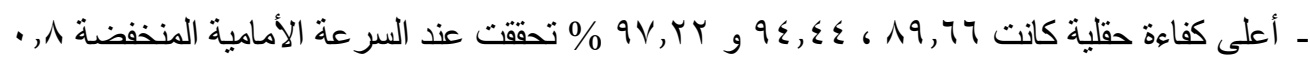

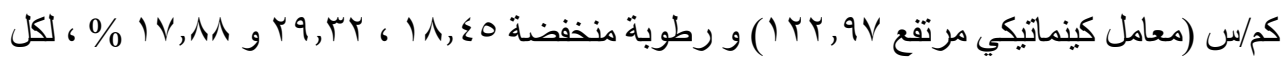

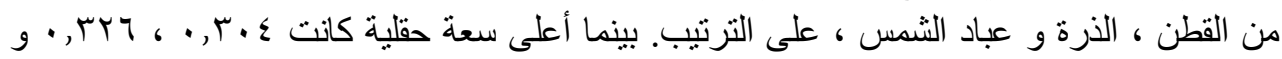

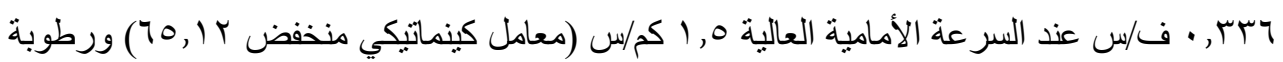

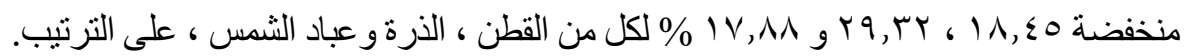

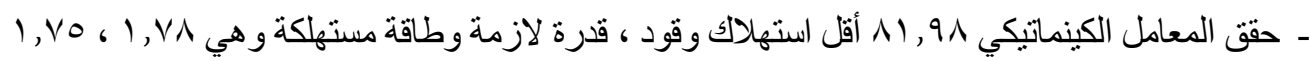

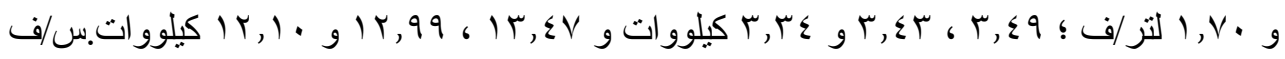

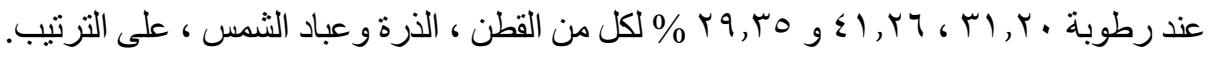

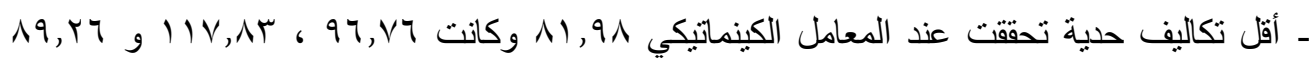

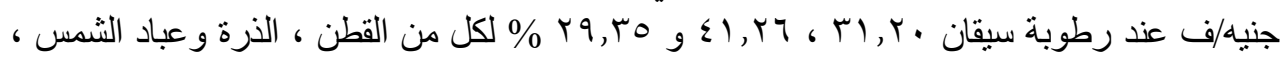
على الترنيب.

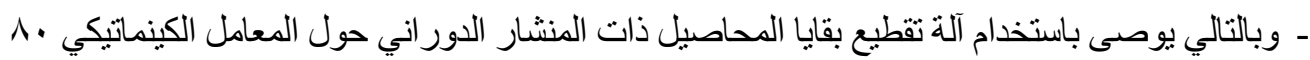

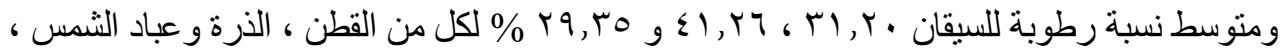
على الترنيب و التي تعطي أقل تكاليف حدية للفدان. 